\begin{tabular}{|c|c|c|c|c|c|}
\hline SRA (India) & $=3.117$ & SIS (USA) & $=0.912$ & ICV (Poland) & $=6.630$ \\
\hline ISI (Dubai, UAE & $=\mathbf{0 . 8 2 9}$ & РИНЦ (Russia) & $=0.156$ & PIF (India) & $=1.940$ \\
\hline IF (Australia) & $=0.564$ & ESJI (KZ) & $=\mathbf{5 . 0 1 5}$ & IBI (India) & $=4.260$ \\
\hline IF & $=1.500$ & SJIF (Morocco) & $=5.667$ & ОАJI (USA) & $=0.350$ \\
\hline
\end{tabular}

Impact Factor:

SOI: $1.1 /$ TAS $\quad$ DOI: $10.15863 /$ TAS

International Scientific Journal Theoretical \& Applied Science

p-ISSN: 2308-4944 (print) e-ISSN: 2409-0085 (online)

Year: 2019 Issue: $01 \quad$ Volume: 69

QR - Issue

QR - Article

Published: $30.01 .2019 \quad$ http://T-Science.org
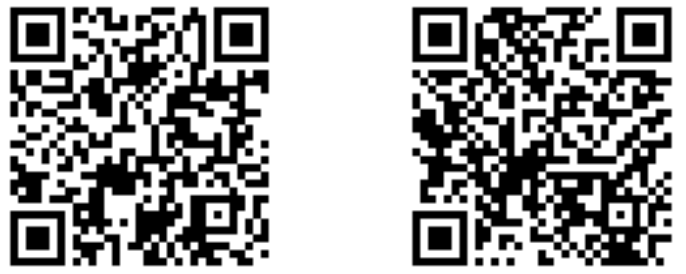

Zia Ullah

Dr., Doctor in Baqai medical university

Karachi, Pakistan

ziasheikh44@gmail.com

Hira Naz Ali

Dr., Doctor in DHQ Teaching Hospital

Sahiwal, Pakistan

hiraali2122@yahoo.com

Junaid Amin

Dr., Medical officer in THQ hospital

Kotli Sialkot, Pakistan

junaidamin13@yahoo.com

\title{
T.B ABDOMEN: FREQUENCY OF COMMON SIGNS AND SYMPTOMS
}

\begin{abstract}
Objective: This study was done to determine frequency of various common signs and symptoms of tuberculous abdomen.

Study design and duration: It is a prospective study started in January 2018 and completed in August 2018 comprising on a total duration of eight months.

Setting: This study was conducted in General surgery unit of Jinnah Hospital Lahore, Pakistan. This is a tertiary care teaching hospital.

Patients and Methods: Total 170 patients presented with the signs and symptoms of acute abdomen in emergency department. These cases were having various features of intestinal obstruction and peritonitis. These cases were evaluated for the cause of acute abdomen. All necessary investigations were carried out in the emergency department after giving initial management. After taking proper history thorough examination was done. X-ray abdomen erect and supine, Ultrasound abdomen, Chest $x$-ray erect, CBC, serum profile and serum amylase were done. Presenting complaints and positive findings were documented. A proforma was designed to document all relevant data of each patient presenting with acute abdomen. Proper consent was taken from each patient for including them in the study and from Medical superintendant of the hospital for conducting study. After evaluation diagnosis was established and definite treatment plan was adopted. All data was analyzed and frequencies were calculated using Microsoft office and SPSS software version 2012. Data was presented in the form of tables and graphs.

Results: Out of 163 cases which presented with acute abdomen, 40 cases were diagnosed with intestinal tuberculosis. This indicates prevalence of T.B abdomen $24.5 \%$ among the cases of acute abdomen. Range of age among these patients was 15-76 years with mean age of 42.4 years. Mostly cases were having age from 25-45 years. There were 25 cases with 15-25 years, 48 cases between 26-35 years age, 40 cases with 36-45 years, 22 cases with 46-55 years, 24 cases with 56-65 years, 8 cases with 66-75 years and only 3 cases were having age above 75 years. Most common presenting symptom among these cases was abdominal pain in all 163 cases followed by constipation, diarrhea and weight loss etc. Most common signs were abdominal tenderness and abdominal distension.

Conclusion: Intestinal tuberculosis is much common among the patients presenting with acute abdomen. Abdominal pain and distension with altered bowel habits are common presenting complaints among these cases. Ileocaecal hyperplastic tuberculosis is most common operative finding in intestinal tuberculosis.
\end{abstract}

Key words: Intestinal tuberculosis, prevalence, presentation of T.B abdomen

Language: English

Citation: Ullah, Z., Ali, H. N., \& Amin, J. (2019). T.B Abdomen: Frequency of common Signs and Symptoms. ISJ Theoretical \& Applied Science, 01 (69), 311-315. 


\begin{tabular}{|c|c|c|c|c|c|c|}
\hline \multirow{4}{*}{ Impact Factor: } & ISRA (India) & $=3.117$ & SIS (USA) & $=0.912$ & ICV (Poland) & $=6.630$ \\
\hline & ISI (Dubai, UAE & $=0.829$ & РИНЦ (Russia & $=0.156$ & PIF (India) & $=1.940$ \\
\hline & GIF (Australia) & $=0.564$ & ESJI (KZ) & $=\mathbf{5 . 0 1 5}$ & IBI (India) & $=4.260$ \\
\hline & JIF & $=1.500$ & SJIF (Morocco & $=5.667$ & OAJI (USA) & $=0.350$ \\
\hline
\end{tabular}

Soi: $\underline{\text { http://s-o-i.org/1.1/TAS-01-69-43 Doi: crossef https://dx.doi.org/10.15863/TAS.2019.01.69.43 }}$

\section{INTRODUCTION}

Mostly patients present in surgical emergency with acute abdomen. Usual complaints are abdominal pain with distension, vomiting, constipation alternating with diarrhea and abdominal tenderness. ${ }^{1}$ They have generally two types of presentation either intestinal obstruction or peritonitis. Patients with obstruction have pain and distended abdomen with exaggerated or absent bowel sounds and constipation. There is no abdominal rigidity like peritonitis in which diarrhea and fever may occur. ${ }^{2}$ All necessary investigations were carried out in the emergency department after giving initial management. After taking proper history thorough examination was done. X-ray abdomen erect and supine, Ultrasound abdomen, Chest $\mathrm{x}$-ray erect, CBC, serum profile and serum amylase were done. ${ }^{5}$ Presenting complaints and positive findings were documented. A proforma was designed to document all relevant data of each patient presenting with acute abdomen. Proper consent was taken from each patient for including them in the study and from Medical superintendant of the hospital for conducting study. After evaluation diagnosis was established and definite treatment plan was adopted. There is no abdominal rigidity like peritonitis in which diarrhea and fever may occur. ${ }^{6}$ Peritonitis is usually due to Intestinal perforation secondary to typhoid fever or T.B abdomen commonly. Peritonitis is usually due to Intestinal perforation secondary to typhoid fever or T.B abdomen commonly. Intestinal tuberculosis is common cause of acute abdomen which initially present with obstruction and latter on with intestinal perforation and peritonitis. ${ }^{3}$ It is usually found in adult age. There may be previous history of pulmonary tuberculosis in the patient or family history positive. This study was done to determine different modes of presentation of such patients and prevalence of T.B abdomen among the cases of acute abdomen. These cases were having various features of intestinal obstruction and peritonitis. These cases were evaluated for the cause of acute abdomen. ${ }^{4}$. Intestinal tuberculosis is common cause of acute abdomen which initially present with obstruction and latter on with intestinal perforation and peritonitis. ${ }^{7}$

\section{Patients and Methods}

This is a prospective study conducted in Nishter Hospital Multan, Pakistan. This is a tertiary care teaching hospital dealing with all types of medical and surgical specialties. This study was completed in duration of Seven months. A proforma was designed to document all relevant data of each patient presenting with acute abdomen. Proper consent was taken from each patient for including them in the study and from Medical superintendant of the hospital for conducting study. After evaluation diagnosis was established and definite treatment plan was adopted. All data was analyzed and frequencies were calculated using Microsoft office and SPSS software version 2012. Data was presented in the form of tables and graphs. All investigations were done with in the Hospital laboratory. Patients with obstruction have pain and distended abdomen with exaggerated or absent bowel sounds and constipation.

All these cases were reported in emergency department. Total 163 patients presented with the signs and symptoms of acute abdomen in emergency department. These cases were having various features of intestinal obstruction and peritonitis. These cases were evaluated for the cause of acute abdomen. All necessary investigations were carried out in the emergency department after giving initial management. After taking proper history thorough examination was done. X-ray abdomen erect and supine, Ultrasound abdomen, Chest x-ray erect, CBC, serum profile and serum amylase were done. Presenting complaints and positive findings were documented

\section{Results}

All the patients presenting in emergency department with acute abdomen were evaluated for T.B Abdomen. Most common presenting symptom among these cases was abdominal pain in all 163 cases followed by constipation, diarrhea and weight loss etc. Most common signs were abdominal tenderness and abdominal distension. Most common symptoms among the patients with intestinal tuberculosis were abdominal pain $163(100 \%)$, abdominal distension 150(92\%), constipation $135(82.8 \%)$, vomiting $110(67.5 \%)$, Diarrhea $27(16.5 \%)$, fever 121(74.2\%), weight loss $117(71.8 \%)$ and night sweats were reported in $24(14.7 \%)$ cases. Common signs were rigidity $84(51.5 \%)$, abdominal mass $11(6.7 \%)$, ascites $55(33.7 \%)$, absent bowel sounds in $138(84.7 \%)$ and increased bowel sounds in 43(26.4\%) cases. 


\begin{tabular}{|c|c|c|c|c|c|c|}
\hline \multirow{4}{*}{ Impact Factor: } & ISRA (India) & $=3.117$ & SIS (USA) & $=0.912$ & ICV (Poland) & $=6.630$ \\
\hline & ISI (Dubai, UAE & $=0.829$ & РИНЦ (Russia) & $=0.156$ & PIF (India) & $=1.940$ \\
\hline & GIF (Australia) & $=0.564$ & ESJI (KZ) & $=5.015$ & IBI (India) & $=4.260$ \\
\hline & JIF & $=1.500$ & SJIF (Morocco) & $=5.667$ & OAJI (USA) & $=0.350$ \\
\hline
\end{tabular}

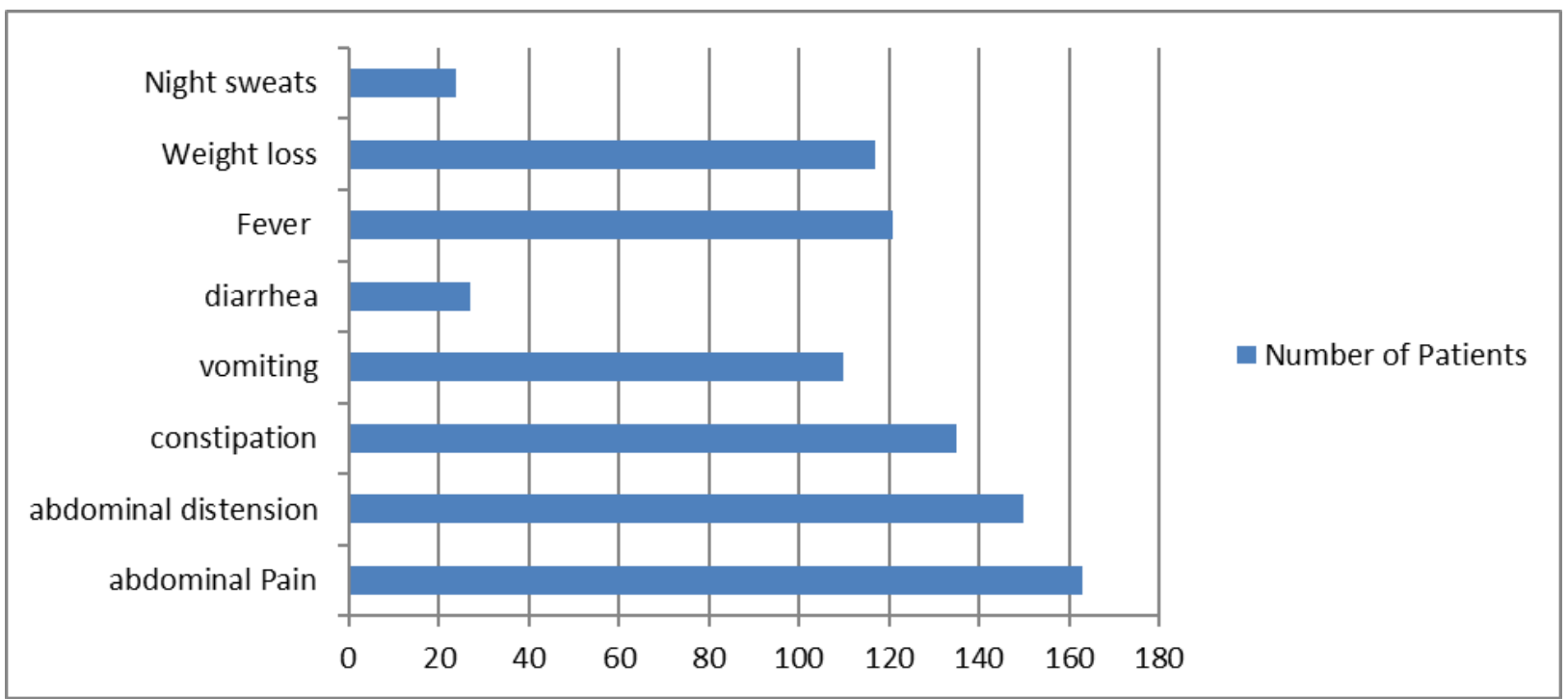

(Figure-1) symptoms in patients with intestinal tuberculosis.

(Table-2) Presenting signs/symptoms in intestinal tuberculosis.

\begin{tabular}{|l|c|c|}
\hline Abdominal Signs in T.B Abdomen & Number of Patients (n) & $(\%)$ \\
\hline Abdominal distension & 140 & 82.4 \\
\hline Abdominal tenderness & 155 & 91.2 \\
\hline Ascites & 45 & 26.5 \\
\hline Peristalsis visible & 11 & 6.5 \\
\hline Absent bowel sounds & 124 & 73.9 \\
\hline Rigidity & 78 & 45.9 \\
\hline Increased bowel sounds & 58 & 34 \\
\hline Abdominal mass & 19 & 11.2 \\
\hline Fever & 129 & 75.9 \\
\hline Weight loss & 107 & 63.9 \\
\hline Night sweats & 31 & 18.2 \\
\hline vomiting & 133 & 78.2 \\
\hline
\end{tabular}




\begin{tabular}{|c|c|c|c|c|c|c|}
\hline \multirow{4}{*}{ Impact Factor: } & ISRA (India) & $=3.117$ & SIS (USA) & $=0.912$ & ICV (Poland) & $=6.630$ \\
\hline & ISI (Dubai, UAE & $=0.829$ & РИНЦ (Russia & $=0.156$ & PIF (India) & $=1.940$ \\
\hline & GIF (Australia) & $=0.564$ & ESJI (KZ) & $=\mathbf{5 . 0 1 5}$ & IBI (India) & $=4.260$ \\
\hline & JIF & $=1.500$ & SJIF (Morocco & $=5.667$ & OAJI (USA) & $=0.350$ \\
\hline
\end{tabular}

\section{DISCUSSION}

Tuberculosis is a worldwide most prevalent disease which can involve any body system. It may affect intestines, spine, kidneys etc. Tuberculosis of spine is called carries spine. Intestinal tuberculosis has prolonged disease course. Such patients give history of night sweats and weight loss from few months. Altered bowel habits and borborygmi are present. ${ }^{10}$ Usually patients complaint of chronic constipation. In acute cases abdominal distension and abdominal pain are present. Intestinal tuberculosis may lead to intestinal perforation. Perforation is usually in ileum. But it may involve any part of intestine. Such cases present with the signs and symptoms of peritonitis. ${ }^{11-14}$ In this situation urgent laparotomy is indicated. Mostly patients present in surgical emergency with acute abdomen. Usual complaints are abdominal pain with distension, vomiting, constipation alternating with diarrhea and abdominal tenderness. Intestinal tuberculosis is common cause of acute abdomen which initially present with obstruction and latter on with intestinal perforation and peritonitis. It is usually found in adult age. There may be previous history of pulmonary tuberculosis in the patient or family history positive. This is a prospective study conducted in Nishter Hospital Multan, Pakistan. ${ }^{17-19}$ This is a tertiary care teaching hospital dealing with all types of medical and surgical specialties. This study was completed in duration of Seven months. All these cases were reported in emergency department. Total 163 patients presented with the signs and symptoms of acute abdomen in emergency department. These cases were having various features of intestinal obstruction and peritonitis. These cases were evaluated for the cause of acute abdomen. All necessary investigations were carried out in the emergency department after giving initial management. ${ }^{20,21}$ After taking proper history thorough examination was done. X-ray abdomen erect and supine, Ultrasound abdomen, Chest x-ray erect, CBC.They have generally two types of presentation either intestinal obstruction or peritonitis. ${ }^{15}$ Patients with obstruction have pain and distended abdomen with exaggerated or absent bowel sounds and constipation. There is no abdominal rigidity like peritonitis in which diarrhea and fever may occur. ${ }^{15,16}$ Peritonitis is usually due to Intestinal perforation secondary to typhoid fever or T.B abdomen commonly.

\section{CONCLUSION}

Tuberculosis is a most prevalent disease all over the world. It is more common in underdeveloped areas and people with low socioeconomic status are affected more than others. Intestinal tuberculosis is much common among the patients presenting with acute abdomen. Abdominal pain and distension with altered bowel habits are common presenting complaints among these cases.

\section{References:}

1. (2002). World Health Organization Bulletin in Epidemiology of Tuberculosis.

2. Suri, S., \& Gupta, S. (1999). CT scan in Abdominal Tuberculosis. Br J Radiol, 72, 9298.

3. Sharp, J. F., \& Goldman, M. (2002). Abdominal Tuberculosis in East Brimingham, a 16 years study. Postgrad Med J, 63, 539-542.

4. Khan, M. R., Khan, I. R., Pal, K. N. M. (2001). Diagnostic issues in Abdominal Tuberculosis. $J$ Pak Med Assoc, 51(4), 138-140.

5. Engin, G., \& Balk, E. (2005, Jan-Feb). Imaging findings of Intestinal Tuberculosis. J Comput Assist Tomogr, 29(1), 37-41.

6. Rita, S. (2001, July-Sept). Diagnosis of Abdominal Tuberculosis. Role of imaging. $J$ Ind Acad Clin Med, 2(3), 103-104.
7. Ahmed, M., Mainghal, M. A. (1999). Pattern of mechanical Intestinal Obstruction in adults. $J$ Coll Physicians Surg Pak, 9, 441-443.

8. Gondal, K. M., \& Khan, A. F. A. (1995). Changing pattern of Abdo-minal Tuberculosis. Pak J Surg, 11, 109-113.

9. (1996). Ministry of Health, Govt. of Pakistan. National Tuberculosis Control Programme 1996-97 to 2001. Islamabad: Ministry of Health, Govt. of Pakistan. p.2-6.

10. Kawaba, F. N. (1993). Abdominal tuberculosis: A study of 881 cases. J R Coll Surg Edin, 38(5), 293.

11. Maqbool, A., Mutti, A., Akram, M. (1998). Ileoceacal Tuberculosis: A study of 31 cases. Pak J Gastroenterol, 12, 45-50.

12. Mahmood, M. T., \& Asghar, R. G. (1993). Abdominal Tuberculosis: A 20 years experience (1971-1990). Pak J Surg, 9, 13-19. 


\begin{tabular}{|c|c|c|c|c|c|c|}
\hline \multirow{4}{*}{ Impact Factor: } & ISRA (India) & $=3.117$ & SIS (USA) & $=0.912$ & ICV (Poland) & $=6.630$ \\
\hline & ISI (Dubai, UAE & $=0.829$ & РИНЦ (Russia) & $=0.156$ & PIF (India) & $=1.940$ \\
\hline & GIF (Australia) & $=0.564$ & ESJI (KZ) & $=5.015$ & IBI (India) & $=4.260$ \\
\hline & JIF & $=1.500$ & SJIF (Morocco) & $=5.667$ & OAJI (USA) & $=0.350$ \\
\hline
\end{tabular}

13. Muneef, M. A., et al. (2001). Tuberculosis in the belly, a review of 46 cases. Scand $J$ Gastroenterol, 36, 528-532.

14. Wadhwa, N., Agarwal, S., \& Mishra, K. (2004, Jan.). Reappraisal of Abdominal Tuberculosis. $J$ Ind Med Assoc, 102(1), 31-32.

15. Moattar, T., et al. (1998). Detection of Mycobacte-rium tuberculosis in paraffin embeded intestinal tissue specimens by polymerase chain reaction: Characterization of IS 6110 element negative strains. J Pak Med Assoc, 48, 174-178.

16. Naz, F., et al. (1999). Abdominal Tuberculosis: A review of 25 cases. Ann King Edward Med Coll, 5, 180-183.

17. Sultan, M. (n.d.). Incidence of Intestinal Tuberculosis in patients presenting as acute emergency with signs of obstructions/peritonitis. [Dissertation for College of Physicians \& Surgeons Pakistan].

18. Boukthir, S., et al. (2004, Jul-Sept). Abdominal Tuberculo-sis in children. Acta Gastroenterol Belg, 67(3), 245-249.
19. Agarwal, P., et al. (1999). Surgical treatment of Abdominal Tuberculosis: A review of 50 cases. Bombay Hosp J, 41.

20. Afsheen, Z., Abrar, M. Q., \& Mohammad, I. (2003). Comparison between strictureplasty and resection anastomosis in Tuberculous Intestinal strictures. J Coll Physicians Surg Pak, 13(5), 227-279.

21. Baluch, M., et al. (1993). Abdominal Tuberculosis; a varied presentation. Pak J Surg, 9(1), 8-12.

22. Sial, K., \& Baloch, Q. (2004, Oct-Dec). Presentation and surgical manage-ment of Abdominal Tuberculosis. Med Channel, 10(4), 20-22.

23. Tariq, N. (1993). Abdominal Tuberculosis. The surgical audit of its presentation. Pak J Surg, 13, 82-86.

24. Sircar, S., Taneja, V. A., \& Kausra, V. (1996). Epidemiology and clinical presentation of Abdominal Tuberculosis, a retrospective study. J Indian Med Assoc, 94(9), 342-344.

25. Naz, F., et al. (1999). Abdominal Tuberculosis: A review of 25 cases. Ann King Edward Med Coll, 5, 180-183. 